\title{
DETERMINASI KADAR LOGAM TIMBAL (Pb) DALAM MAKANAN KALENG MENGGUNAKAN DESTRUKSI BASAH DAN DESTRUKSI KERING
}

\author{
Diana Candra De wi. ${ }^{1}$ \\ ${ }^{1}$ Jurusan Kimia Fakultas Sains dan Teknologi UIN Maliki Malang
}

\begin{abstract}
Lead $(\mathrm{Pb})$ is pollutant found in canned foods. It is derived from the soldering between the can and the lid. This study aims to find out the analytical performance of standar curves, the better method between dry ashing dan wet ashing, the best oxidant solution in wet ashing ang determine lead in canned sausage and canned lychee. This research including : Performance determination of the standard addition curve analysis includes linearity, limits of detection and limits of quantitation, sensitivity, accuracy and precision, sample destruction using dry ash $500{ }^{\circ} \mathrm{C}$ and wet destruction with a variety of oxidizing subtrace such as $\mathrm{HNO}_{3}$ p.a; $\mathrm{HNO}_{3}$ p.a, $\mathrm{H}_{2} \mathrm{SO}_{4}$ p.a (3:1), and $\mathrm{HNO}_{3}$ p.a, $\mathrm{H}_{2} \mathrm{SO}_{4}$ p.a, $\mathrm{H}_{2} \mathrm{O}_{2}$ p.a (6:2:1), and determine the concentration of lead in canned sausage and canned lychee

The results of this research of the standard curve analysis of lead $(\mathrm{Pb})$ are $\mathrm{r}=0,9999$, LOD 0,028 ppm, LOQ $0,0933 \mathrm{ppm}$, and sensitivity of 0,00757 the average accuracy of $98 \%$, and precision $2,74 \%$. Wet ashing is more stabil than dry ashing. The best oxidizing substance of canned sausage comes from $\mathrm{HNO}_{3}, \mathrm{H}_{2} \mathrm{SO}_{4}$ and $\mathrm{H}_{2} \mathrm{O}_{2} \quad$ (6:2:1) and lead was found $0,64 \mathrm{ppm}$ while best oxidizing substance of canned lychee comes from $\mathrm{HNO}_{3}$, $\mathrm{H}_{2} \mathrm{SO}_{4}$ (3:1) and lead was found $0,72 \mathrm{ppm}$.
\end{abstract}

Key words : lead $(P b)$, canned food, wet ashing, dry ashing

\section{ABSTRAK}

Timbal $(\mathrm{Pb})$ adalah bahan pencemar yang ditemukan dalam makanan kaleng yang berasal dari patrian antara badan kaleng dengan tutupnya. $\mathrm{Pb}$ dalam jumlah kecil tidak berbahaya bagi manusia namun jika jumlahnya melampaui batas dapat menyebabkan keracunan akut maupun kronis. Penelitian ini bertujuan untuk mengetahui performa analitik kurva standar, penentuan zat pengoksidasi terbaik serta menentukan kadar logam $\mathrm{Pb}$ dalam sosis dan leci kaleng dengan destruksi kering dan basah. Metode penelitian ini meliputi : Optimasi instrumen Spektrofotometri Serapan Atom, preparasi larutan standar Pb untuk menentukan performansi analitik yaitu linearitas, batas deteksi dan batas kuantitasi, sensitivitas, akurasi serta presisi, preparasi sampel dengan destruksi kering dengan suhu $500{ }^{\circ} \mathrm{C}$, preparasi sampel dengan destruksi basah menggunakan variasi zat pengoksidasi seperti $\mathrm{HNO}_{3}$ p.a; $\mathrm{HNO}_{3}$ p.a, $\mathrm{H}_{2} \mathrm{SO}_{4}$ p.a (3:1); dan $\mathrm{HNO}_{3}$ p.a, $\mathrm{H}_{2} \mathrm{SO}_{4}$ p.a, $\mathrm{H}_{2} \mathrm{O}_{2}$ p.a (6:2:1), dan analisis kadar $\mathrm{Pb}$ pada sampel setelah destruksi. Hasil penelitian didapatkan performa analitik untuk kurva standar timbal $(\mathrm{Pb})$ meliputi $\mathrm{r}=0,999$, LOD 0,028, LOQ 0,093 ppm, sensitivitas 0,007, rerata akurasi 98\%, dan presisi 2,74\%. Hasil analisis $\mathrm{Pb}$ dalam makanan kaleng sosis dan leci yang dipreparasi dengan cara destruksi kering tidak memberikan hasil yang stabil. Hasil analisis kadar $\mathrm{Pb}$ dalam sosis kaleng adalah 0,64 ppm dengan zat pengoksidasi terbaik campuran $\mathrm{HNO}_{3}, \mathrm{H}_{2} \mathrm{SO}_{4}$ dan $\mathrm{H}_{2} \mathrm{O}_{2}$ (6:2:1), sedangkan kadar $\mathrm{Pb}$ dalam leci kaleng adalah 0,72 ppm dengan zat pengoksidasi campuran $\mathrm{HNO}_{3}$, dan $\mathrm{H}_{2} \mathrm{SO}_{4}$ (3:1).

Kata kunci : timbal (Pb), makanan kaleng, destruksibasah, destruksikering

\section{PENDAHULUAN}

Makanan maupun minuman
dikemas secara khusus untuk dapat memperpanjang umur makanan tersebut. Biasanya tempat yang digunakan adalah kaleng, akan tetapi makanan kaleng dapat menyerap logam dari wadahnya baik timah $(\mathrm{Sn})$, seng $(\mathrm{Zn})$ dan besi $(\mathrm{Fe})$ dari pelat timah, serta timah $(\mathrm{Sn})$ dan timbal $(\mathrm{Pb})$ dari patrian (Cahyadi, 2004). Pada makanan yang bersifat asam dan dikalengkan tanpa oksigen, timah menjadi anoda dalam pasangan timah-besi. Timah pada kondisi ini larut dengan laju sangat rendah dan dapat melindungi produk selama dua tahun atau lebih. Sosis dan buah leci kalengan masih dimungkinkan adanya logam pencemar dari hasil patrian antara badan kaleng dengan tutup kaleng yang menggunakan timah $(\mathrm{Sn})$ dan timbal $(\mathrm{Pb})$. 
Timbal merupakan logam yang berwarna abu-abu, mempunyai titik didih $1620{ }^{\circ} \mathrm{C}$ dan titik leleh $327,5{ }^{\circ} \mathrm{C}$, lunak dan dapat ditempa serta sukar menghantar arus listrik. Biasanya timbal digunakan sebagai logam campuran dalam pematrian tutup makanan kemasan kaleng. Dalam jumlah kecil timbal dalam makanan kaleng tidak berbahaya terhadap manusia akan tetapi apabila jumlah timbal dalam keadaan yang melampui batas maka akan terjadi keracunan baik secara akut maupun kronis. Di Indonesia badan yang menentukan kadar dari masing-masing mikroba dan cemaran adalah BPOM (Badan Pengawas Obat dan makanan) dan SNI (Standar Nasional Indonesia). Adapun batas Timbal (Pb) dalam makanan kaleng yang diperbolehkan menurut badan BPOM Nomor HK.00.06.1.52.4011 dan SNI Nomor 7387:2009 adalah 1,0 mg/kg untuk daging olahan seperti sosis, kornet, bakso dan lainlain. Susilawati (2009)

Kemasan kaleng termasuk jenis kemasan yang banyak digunakan. Spesifikasi kaleng untuk mengemas pangan ditentukan oleh dua kebutuhan yaitu kebutuhan akan kekuatan yang dimiliki wadah dan daya simpan yang dimiliki oleh produk dalam kaleng. Kebutuhan terhadap daya simpan isi kaleng salah satunya ditentukan oleh sifat korosif produk. Untuk mengemas produk pangan, maka bagian dalam kaleng (sebagaimana halnya bagian luar kaleng) harus bersifat tahan korosi (karat). Pada bagian dalam kaleng, korosi dapat disebabkan oleh kontak langsung antara produk dan permukaan kaleng. Beberapa faktor yang menentukan terjadinya pembentukan karat pada bagian dalam kaleng antara lain sifat bahan pangan, terutama $\mathrm{pH}$ (baik dalam kadar asam yang tinggi maupun rendah) sehingga terjadi pembentukan karat seperti nitrat, beberapa bahan belerang, zat warna antosianin; banyaknya sisa oksigen dalam bahan pangan, khususnya pada ruang udara; suhu dan waktu penyimpanan; serta beberapa faktor yang berasal dari bahan kemas, seperti berat lapisan timah, macam dan komposisi lapisan baja dasar, efektifitas perlakuan pada permukaan lapisan, jenis lapisan dan lain sebagainya (Syamsir, 2008).

Dalam kemasan kaleng, makanan dapat dipanaskan hingga suhu yang sangat tinggi dan tekanan yang tinggi pula. Dengan demikian semua mikroba yang hidup bersama makanan tersebut akan mati. Karena kaleng juga ditutup dengan sangat rapat, maka mikroba baru tidak akan bisa masuk kembali ke dalamnya. Oleh karena itu makanan kaleng dapat disimpan hingga dua tahun dalam keadaan baik, tidak busuk, dan tidak beracun. Semua jenis makanan bisa dikemas di dalam kaleng. Mulai dari daging, ikan, sayuran, buah-buahan dan makanan olahan seperti sosis, cornet, bumbu dan lain lain (Winarno,1994).

Kaleng timah (tin can) merupakan pengembangan dari penemuan Nicolas Francois Appert pada dasawarsa 1800-an. Berkat penemuan produksi massal, pada akhir abad ke-19, kaleng yang berbahan dasar timah $(\mathrm{Sn})$ menjadi standar produk konsumen. Produk-produk makanan maupun minuman yang biasanya mengalami proses pengalengan ataupun menggunakan kaleng sebagai tempat (wadahnya) adalah produk-produk yang disterilisasi dengan panas.

Wadah kaleng pada umumnya digunakan untuk berbagai produk yang mengalami proses sterilisasi termal. Pada mulanya wadah kaleng dibuat dari plat timah (tin plate) yang terdiri dari lembaran dasar baja timah putih (Sn) panas (hot dipping) atau dengan proses elektrolisa. Kemudian berkembang berbagai jenis yang berbeda dengan plat timah standar, seperti misalnya kaleng baja bebas timah. Bentuk dari kemasan kaleng itu sendiri dibedakan menjadi dua jenis yaitu kaleng two piece cans dan kaleng three piece. Three fiece cans adalah kaleng yang terdiri dari tiga sambungan yaitu dibagian badan kaleng, di bagian tutup atas kaleng dan sebagian tutup bawah kaleng. Sedangkan two piece cans adalah kaleng yang secara keseluruhan hanya memiliki satu sambungan, yaitu di 
bagian tutup atas kaleng. Kerusakan produk pangan kaleng terutama disebabkan karena interaksi antara logam dasar pembuat kaleng, yaitu Sn dan Fe yang dapat menyebabkan perubahan yang tidak diinginkan seperti perubahan warna, terjadi off-flavour, kehilangan nilai nutrisi, dan terbentuknya karat pada kaleng. Selain itu bagian sambungan kaleng yang disolder dapat menyebabkan terjadinya kontak antara $\mathrm{Sn}$ dan $\mathrm{Pb}$ dari solder dengan produk pangan yang memiliki kadar asam rendah $(\mathrm{pH}>4,6$ - 7) sehingga terjadi sulfide stain atau noda hitam pada produk kaleng. Produk pangan yang memiliki kadar asam semakin rendah, maka pemanasan yang diperlukan semakin ringan. Produk pangan yang diasamkan sampai $\mathrm{pH} 4.6$ atau lebih rendah tidak memerlukan proses panas yang tinggi tetapi $\mathrm{pH}$ harus dikontrol dengan benar. Logam $\mathrm{Sn}$ dan $\mathrm{Fe}$ yang merupakan logam dasar pembuat kemasan kaleng termasuk kedalam golongan logam berat. Jika produk pangan kaleng yang terkontaminasi logam berat masuk kedalam tubuh manusia akan menimbulkan suatu keracunan. Hal ini disebabkan logam berat yang mempunyai kemampuan sebagai cofaktor enzim, akibatnya enzim tidak dapat berfungsi sebagaimana biasanya sehingga reaksi metabolisme terhambat. Untuk menghindari itu perlu dilakukan analisis logam berat $\mathrm{Pb}, \mathrm{Fe}$ dan $\mathrm{Sn}$ misalnya dengan menggunakan instrumen seperti SSA (Spektroskopi Serapan Atom) (Tarigan, 2010).

Penentuan mineral dalam bahan pangan harus melalui proses destruksi. Destruksi merupakan proses perusakan oksidatif dari bahan organik sebelum penetapan suatu analit anorganik atau untuk memecah ikatan dengan logam. Metode tersebut digunakan untuk menghilangkan efek matriks pada sampel. Dalam pendestruksian hendaknya memilih zat pengoksidasi yang cocok baik untuk logam maupun jenis makanan yang akan dianalisis. Penentuan mineral dalam bahan pangan harus melalui proses destruksi. Destruksi ada dua yaitu destruksi kering dan destruksi basah. Dalam preparasi destruksi basah untuk sampel yang berbahan dasar daging masih didapatkan zat pengoksidasi yang berbeda-beda seperti $\mathrm{HNO}_{3}$ p.a, $\mathrm{H}_{2} \mathrm{SO}_{4}$ p.a dan $\mathrm{H}_{2} \mathrm{O}_{2}$ p.a ataupun percampuran diantara ketiganya

Destruksi basah dilakukan dengan cara menguraikan bahan organik dalam larutan oleh asam pengoksidasi pekat dan panas seperti $\mathrm{H}_{2} \mathrm{SO}_{4}, \mathrm{HNO}_{3}, \mathrm{H}_{2} \mathrm{O}_{2}$ dan $\mathrm{HClO}_{4}$ dengan pemanasan sampai jernih. Mineral anorganik akan tertinggal dan larut dalam larutan asam kuat. Mineral berada dalam bentuk kation logam dan ikatan kimia dengan senyawa organik telah terurai. Larutan selanjutnya disaring dan siap dianalisis dengan SSA. Destruksi kering dilakukan dengan cara sampel yang akan dianalisis dipanaskan pada temperatur lebih dari $500{ }^{\circ} \mathrm{C}$. Keuntungan yang akan diperoleh selain sederhana, juga dapat terhindar dari pengotor seperti yang terdapat dalam metode destruksi basah. Kemungkinan yang dapat terjadi adalah terdapat reaksi antara unsur dan wadah yang terbiat dari silikat.Unsur-unsur dalam sampel dapat teradsorbsi pada permukaan wadah dengan membentuk senyawaan silikat. (Maria, 2010).

\section{METODE PENELITIAN}

\section{ALAT}

Seperangkat instrumen Spektroskopi Serapan Atom (SSA) merek Varian spectra AA 240, Peralatan alat gelas Laboratorium, Neraca analitik merek Kern, Hot Plate stirer, Kertas Whatman 42.

\section{BAHAN}

Larutan standar $\mathrm{Pb}$ E Merck, $\mathrm{H}_{2} \mathrm{O}_{2}$ p.a, $\mathrm{H}_{2} \mathrm{SO}_{4}$ p.a, $\mathrm{HNO}_{3}$ p.a, aquabidest, aquadest dan sosis dan leci kaleng.

\section{CARA KERJA}

\section{Pembuatan Kurva Standar}

Larutan Standar $\mathrm{Pb}$ induk 1000 $\mathrm{mg} / \mathrm{L}$ dibuat dari larutan dengan merek EMerck. Larutan $\mathrm{Pb} 10 \mathrm{mg} / \mathrm{L}$ dibuat dengan cara memindahkan $1 \mathrm{~mL}$ larutan baku 1000 mg/L ke dalam labu ukur 100 ml kemudian 
diencerkan sampai batas. Larutan standar $\mathrm{Pb} \quad 0,5 \mathrm{mg} / \mathrm{L} ; 1,0 \mathrm{mg} / \mathrm{L} ; \quad 2,0 \mathrm{mg} / \mathrm{L} ; 3,0$ $\mathrm{mg} / \mathrm{L}$ dan $4,0 \mathrm{mg} / \mathrm{L}$ dibuat dengan cara memindahkan $2,5 \mathrm{~mL} ; 5 \mathrm{~mL} ; 10 \mathrm{~mL} ; 15$ $\mathrm{mL}$ dan $20 \mathrm{~mL}$ larutan baku $10 \mathrm{mg} / \mathrm{L}$ ke dalam labu ukur $50 \mathrm{~mL}$ kemudian diencerkan sampai batas.

Sederetan larutan standar $\mathrm{Pb}$ dianalisis dengan Spektrofotometer Serapan Atom (SSA) Varian Spectra AA 240 pada kondisi sebagai berikut : alat Spektrofotometer serapan atom Varian Spectra AA 240 meliputi panjang gelombang pada 283,3 nm, Laju alir asetilen pada 2,0 L/menit, Laju alir udara pada 10,0 L/menit, Lebar celah pada 0,5 $\mathrm{nm}$, Kuat arus $\mathrm{HCl} 10,0 \mu \mathrm{A}$, Tinggi burner $2,0 \mathrm{~mm}$

Setelah didapatkan kurva standar maka dilakukan perhitungan terhadap performa analitik kurva standar yang meliputi linearitas, batas deteksi dan batas kuantitasi, sensitivitas, akurasi serta presisi. Selanjutnya dilakukan preparasi sampel menggunakan destruksi basah dan kering

\section{Preparasi Sampel}

Sosis dan leci dioven pada suhu 70 C terlebih dahulu sampai berat kering diperoleh dengan konstan. Cairan sosis dan leci yang terdapat dalam sampel disaring dengan kertas Whatman 42 .

\section{Destruksi kering}

Sampel sosis kering dan leci kering ditimbang secara kuantitatif sebanyak 1 gr ke dalam krus porcelain ukuran $5 \mathrm{ml}$. Sebelum ditanur sampel ditetesi dengan zat pengoksidasi yaitu $\mathrm{HNO}_{3}$ p.a 5 tetes. Selanjutnya sampel dimasukkan dalam tanur yang sudah dipanaskan pada suhu 100 ${ }^{\circ} \mathrm{C}$ selama 30 menit dan tanur dipanaskan hingga suhu $500{ }^{\circ} \mathrm{C}$ selama 2 jam. Apabila sampel telah berwarna putih keabu abuan maka tanur dimatikan dan dibiarkan sampai suhu kamar.

\section{Analisis Pb}

Sampel dikeluarkan dari tanur dan dilarutkan dengan larutan $\mathrm{HNO} 3 \quad 0,5 \quad \mathrm{M}$ menggunakan labu takar $50 \mathrm{ml}$ sampai tanda batas. Larutan diukur kadar $\mathrm{Pb}$ terlarut menggunakan SSA. Dilakukan pengulangan tiga kali.

\section{Destruksi basah}

Sampel sosis kering dan leci kering ditimbang secara kuantitatif sebanyak 1 gr dalam gelas beaker ukuran $100 \mathrm{~mL}$ lalu ditambahkan dengan $30 \mathrm{~mL} \mathrm{HNO3} \mathrm{p.a} \mathrm{dan}$ zat pengoksidasi lain (sesuai komposisi). kemudian dipanaskan sampai volume berkurang setengahnya di atas hot plate hal ini dimaksudkan untuk menguapkan sebanyak mungkin zat organik yang ada. Apabila larutan masih berwarna keruh maka ditambahkan HNO3 p.a dan zat pengoksidasi yang lain (sesuai komposisi).

Adapun zat pendestruksi yang digunakan adalah sebagai berikut:

a) $\mathrm{HNO}_{3}$ p.a

b) $\mathrm{HNO}_{3}$ p.a $+\mathrm{H}_{2} \mathrm{SO}_{4}$ p.a $(3: 1)$

c) $\mathrm{HNO}_{3}$ p.a $+\mathrm{H}_{2} \mathrm{SO}_{4}$ p.a $+\mathrm{H}_{2} \mathrm{O}_{2}$ p.a (6:2:1)

\section{Analis is $\mathbf{P b}$}

Sampel yang telah didestruksi, dipindahkan ke dalam labu takar $50 \mathrm{ml}$ dan diencerkan dengan larutan $\mathrm{HNO}_{3} \quad 0,5 \quad \mathrm{M}$ sampai tanda batas. Larutan diukur kadar $\mathrm{Pb}$ terlarut menggunakan SSA. Dilakukan pengulangan tiga kali. Penentuan oksidator terbaik dapat dilihat pada stabilitas larutan.

\section{Analisis Data}

Data pembuatan kurva standar dan adisi standar terdapat hubungan antara Konsentrasi (C) dengan Absorbansi (A) maka nilai yang dapat diketahui adalah nilai slope dan intersep, Kemudian nilai konsentrasi sampel dapat diketahui dengan memasukkan ke dalam persamaan regresi linear dengan menggunakan hukum Lambert-Beer yaitu:

$\mathrm{Y}=\mathrm{Bx}+\mathrm{A}$

Dimana :

$$
\begin{aligned}
\mathrm{Y} & =\text { Absorbansi Sampel } \\
\mathrm{B} & =\text { Slope } \\
\mathrm{X} & =\text { Konsentrasi sampel } \\
\mathrm{A} & =\text { Intersep }
\end{aligned}
$$


Untuk mengetahui performa analitik dari metode destruksi basah dengan variasi zat pengoksidasi ini dilakukan analisa statistik yang meliputi hal berikut :

\section{Penentuan Linearitas}

Linearitas merupakan daerah (range) konsentrasi analit tertentu pada grafik absorbansi terhadap konsentrasi yang memberikan respon linier dimana kenaikan absorbansi berbanding lurus dengan kenaikan konsentrasi (Skoog, 1985).

Respon linear ditunjukkan melalui persamaan garis sebagai berikut:

$y=b x+a$

dimana :

$\mathrm{b}=$ slope atau kemiringan kurva standar

$\mathrm{a}=$ Intersep atau perpotongan terhadap sumbu $\mathrm{y}$

\section{Penentuan Batas Deteksi dan Batas Kuantitasi}

Batas deteksi adalah kuantitas (konsentrasi) terkecil suatu analit yang masih dapat ditentukan atau dideteksi. Pada penelitian ini, konsentrasi yang digunakan adalah 0 ppm, 0,5 ppm, 1 ppm, 2 ppm, 3 ppm, dan 4 ppm.

Nilai Sy/x dimasukkan dalam persamaan berikut (Miller, 1991):

$\mathrm{Y}_{\mathrm{LOD}}=\mathrm{A}+3 \mathrm{SD}$

Keterangan :

$\mathrm{SD}=\mathrm{Sy} / \mathrm{x}=$ Standar Deviasi Kurva standar A $=$ Intersep Kurva standar

Batas kuantitasi diperoleh dari persamaan (Miller, 1991): LOQ $=10 \times$ LOD

\section{Sensitivitas}

Sensitivitas merupakan rasio perubahan sinyal tiap unit perubahan konsentrasi analit. Sensitivitas dapat dinyatakan sebagai slope kurva yang diperoleh dengan rentang tertentu. Hal ini sesuai dengan aturan IUPAC, bahwa sensitivitas yang dinyatakan dengan slope merupakan sensitivitas kurva. Nilai sensitivitas yang besar menunjukkan perubahan konsentrasi analit yang kecil dan dapat memberikan respon yang berarti.

\section{Akurasi}

Merupakan kemampuan suatu metode analisa untuk memperoleh nilai yang sebenarnya (ketepatan pengukuran). Akurasi diperoleh dengan menghitung persen recovery. Persamaan untuk persen recovery adalah.:

$$
\% \text { Recovery }=\frac{\text { Hasil Analisis } \times 100 \%}{\text { Nilai Sebenarnya }}
$$

\section{HASIL DAN PEMBAHASAN}

\section{Optimasi Kurva Kalibrasi}

Panjang gelombang yang dipilih adalah 283,3 $\mathrm{nm}$ karena panjang gelombang ini merupakan panjang gelombang paling kuat menyerap garis untuk transisi elektronik dari tingkat dasar ke tingkat eksitasi. Apabila atom pada tingkat energi dasar diberi energi yang sesuai maka energi tersebut akan diserap dan atom-atom tersebut akan tereksitasi ke tingkat energi yang lebih tinggi. Pada keadaan tereksitasi, atom tidak stabil sehingga akan kembali ke tingkat energi dasar dengan melepas sejumlah energi dalam bentuk sinar. Maka setiap panjang gelombang mempunyai energi yang spesifik. Timbal mempunyai energi sebesar 7,0134 .10 ${ }^{-8}$ Joule, dimana dengan energi tersebut akan menyebabkan atom $\mathrm{Pb}$ dalam keadaan dasar $\left(\mathrm{Pb}^{\circ}\right)$ tereksitasi ke tingkat energi yang lebih tinggi $(\mathrm{Pb} *)$.

Lebar celah dapat mengontrol gangguan spektra tertentu, misalnya garisgaris yang terabsorpsi dari gas pengisi lampu katoda cekung, garis-garis yang tidak teradsorpsi dari logam katoda, dan pita-pita molekul dalam nyala. Pengaturan sinar yang masuk mengurangi gangguan ini, tetapi tidak seluruhnya efektif. Gangguan-gangguan ini dapat dikontrol dengan mengurangi lebar celah. Lebar celah yang sensitif sekitar $10 \mu \mathrm{m}$ yang dapat menghasilkan setengah lebar intensitas dari garis yang dipancarkan oleh lampu katoda cekung melalui pita molekul. Pada 
penelitian ini kondisi optimum lebar celah adalah 0,5 nm (merujuk pada ketetapan panjang gelombang) dimana lebar celah logam timbal $(\mathrm{Pb})$ memiliki ukuran lebih kecil dari $10 \mu \mathrm{m}$, ini menunjukkan bahwa ukuran lebar celah lebih kecil, sehingga lebar celah lebih efektif untuk mengurangi adanya gangguan spectra. Semakin kecil lebar celah yang dilakukan akan memperkecil gangguan spektranya.

Lebar celah monokromator harus dipilih untuk mengoptimasi signal to noise ratio. Lebar celah dalam spektrofotometri serapan atom harus sebesar yang diperlukan untuk mengisolasi garis spektra yang digunakan (garis resonansi). Lebar celah yang sangat sempit diperlukan hanya bila spektra emisi sumber radiasi adalah sangat kompleks dan memiliki garis resonansi yang akan digunakan.

Bagian katoda yang berbentuk cekung dilapisi logam yang sesuai dengan logam yang akan di analisis. Anoda diberi tegangan sehingga bila sejumlah kecil arus yang besarnya beberapa mA diberikan di antara katoda dan anoda akan mengakibatkan gas argon yang ada di dalam tabung akan mengalami ionisasi, akibatnya ion gas argon tersebut akan tertarik ke arah katoda (yang bermuatan negatif) dengan kecepatan yang sangat tinggi dan terjadi tumbukan yang mengakibatkan tereksitasinya atom-atom logam yang bersangkutan. Dalam hal ini berlaku hukum emisi atom yang menyatakan bila atom mempunyai kelebihan tenaga maka akan melepaskan kembali tenaga yang berupa sinar panjang gelombang yang karakteristik. Dengan demikian sinar dari lampu katoda cekung ini mempunyai spectrum yang spesifik sesuai dengan panjang gelombangnya yaitu 283,3 nm dengan kuat arus 10,0 $\mu \mathrm{A}$.

Kuat arus lampu katoda cekung yang dianjurkan tergantung pada unsur yang akan di analisis dan bervariasi. Pemakaian kuat arus di usahakan seoptimal mungkin, karena pemberian kuat arus yang terlalu rendah akan menyebabkan intensitas lampu menjadi terlalu rendah sehingga energi yang diberikan juga rendah (Underwood, 2002).

Efisiensi lampu katoda cekung bergantung pada bentuk geometri dari katodanya dan besarnya tegangan atau arus yang diberikan. Peningkatan pemberian arus pada lampu katoda, pada umumnya akan meningkatkan intensitasnya, tetapi akan mengurangi umur dari lampu tersebut. Walaupun demikian peningkatan intensitas ini ada batasnya, karena hal sebaliknya mungkin saja terjadi, yaitu pemberian arus yang terlalu tinggi akan mengakibatkan terjadinya peningkatan jumlah atom-atom yang tidak tereksitasi dalam awan atom dan menyerap emisi yang dipancarkan sehingga dapat terjadi apa yang disebut penyerapan diri dan hal ini dapat mengurangi intensitas (Underwood, 2002)

Laju alir asetilen-udara yang digunakan sebagai bahan pembakar dan oksida untuk logam $\mathrm{Pb}$ adalah 2,0 L/menit dan 10,0 L/menit. Asetilen-udara berfungsi membawa sampel dalam bentuk larutan agar masuk ke dalam sistem pengkabutan yang akan mengubah sampel larutan menjadi aerosol halus (uap) yang siap masuk ke dalam system nyala untuk atomisasi. Beberapa kelebihan gas pembakar dan oksidator asetilen-udara yaitu dapat memberikan hasil yang maksimal, digunakan untuk berbagai unsur dan memiliki sensitivitas dan kecermatan yang tinggi. Laju alir gas pembakar dan oksidator yang dibutuhkan tergantung pada ukuran pembakar (burner dan komponenkomponen sampel).

Atom- atom dalam nyala tidak merata distribusinya karena di dalam nyala terdapat beberapa daerah panas. Untuk mengatasi hal ini maka dilakukan optimasi pada tinggi burner (Aziz, 1997).

Kurva standar dibuat berdasarkan hukum Lambert-Beer. Yaitu $\mathrm{A}=\mathrm{abc}$. Absorbansi (A) sebagai Absis. Oleh karena itu, konstanta yang harga perkaliannya ditentukan oleh Slope adalah nilai untuk a dan b. Sehingga jika dibuat kurva absorbansi lawan konsentrasi larutan standar, maka dapat diperoleh kurva garis 
lurus. Dari perhitungan regresi linier yaitu y $=\mathrm{bx}+\mathrm{a}$, maka penarikan garis lurus dapat dilihat atau diambil.

Hubungan linear antara $\mathrm{X}$ dan $\mathrm{Y}$ dapat diketahui melalui harga koefisien korelasi (r). Pada umumnya $r=0,999$ berarti kurva linear memiliki slope positif (Khozanah, 2004). Larutan standar $\mathrm{Pb}$ dibuat dari larutan stok Pb E-Merck 1000 ppm, dimana larutan standar ini diencerkan menjadi 10 ppm kemudian diencerkan lagi menjadi deretan larutan standar yaitu 0,$5 ; 1$; 2; 3 dan 4 ppm. Pengenceran dilakukan dengan $\mathrm{HNO}_{3} \quad 0,5 \mathrm{M}$ karena matriks dalam larutan standar harus sama dengan matriks dalam sampel. Pengukuran absorbansi larutan standar menggunakan alat nyala SSA. Dimana absorbansi menunjukkan kemampuan sampel untuk menyerap radiasi elektromagnetik pada panjang gelombang maksimum. Kurva kalibrasi larutan standar logam $\mathrm{Pb}$ dapat dilihat pada Pengukuran absorbansi larutan standar menggunakan alat nyala SSA. Kurva kalibrasi larutan standar logam $\mathrm{Pb}$ dapat dilihat pada Gambar 1.

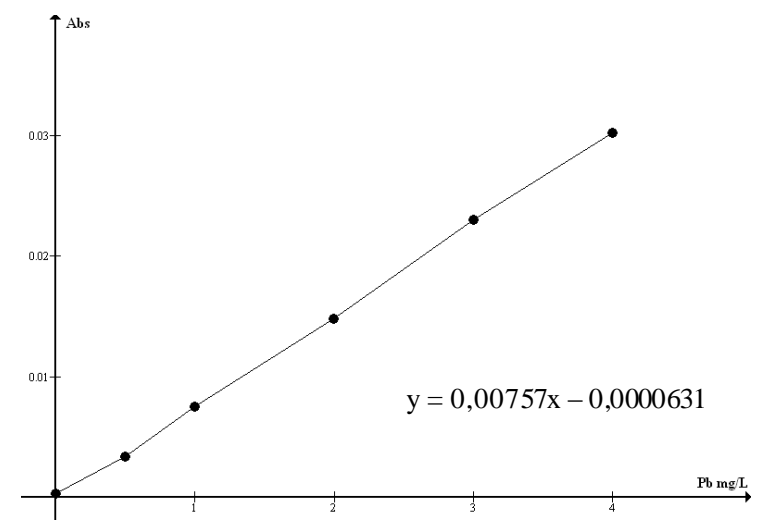

Gambar 1. Grafik kurva standar timbal $(\mathrm{Pb})$

Validasi metode analitik untuk kurva standar timbal (pb) adalah sebagai berikut:

- Linearitas dari kurva standar timbal $(\mathrm{Pb})$ adalah 0,9999, artinya $\pm 99 \%$ perubahan absorbans dipengaruhi oleh perubahan konsentrasi timbal $(\mathrm{Pb})$, sedangkan $\pm 1 \%$ dipengaruhi faktor lain.

- Batas terkecil dari suatu analit yang masih dapat ditentukan atau dideteksi oleh kurva standar $\mathrm{Pb}$ berdasarkan perhitungan pada lampiran adalah LOD $=0,028 \mathrm{ppm}$ dan LOQ = 0,0933 ppm

- Sensitivitas dari kurva standar $\mathrm{Pb}$ adalah 0,00757. Nilai ini menunjukan bahwa tiap satu satuan perubahan konsentrasi akan menghasilkan perubahan absorbansi sebesar 0,00757

- Akurasi dari kurva standar timbal $(\mathrm{Pb})$ yang dinyatakan dalam \% recovery adalah 91,4\% untuk 0,5 ppm; 99,9\% untuk 1 ppm; 98\% untuk 2 ppm; 101,3 $\%$ untuk 3 ppm dan 99,75\% untuk 4 ppm. Priyambodo (2011) menyatakan persyaratan dari akurasi adalah persen recovery berada pada range $98-102 \%$.

- Presisi $2,74 \%$. Karena nilai koefisien variasi dari kurva baku timbal $(\mathrm{Pb})$ dibawah 5\% maka dapat dinyatakan bahwa presisi kurva baku adalah sensitif untuk menganalisa logam timbal $(\mathrm{Pb})$.

\section{Preparasi Sampel}

\section{Preparasi Sampel dengan destruksi basah}

Preparasi sampel merupakan langkah yang penting dalam analisis unsurunsur mikro yang menggunakan pengukuran Spektrofotometri Serapan Atom. Pemilihan metode preparasi sampel sangat mempengaruhi hasil yang akan didapatkan nantinya. Dalam menganalisis konsentrasi suatu logam di dalam suatu sampel, ternyata semua elemen ataupun komponen dalam hal ini yang tidak ingin kita amati dapat menyebabkan kenaikan ataupun penurunan konsentrasi logam yang ingin kita analisis, untuk itu perlu dilakukan pengenceran larutan sampel untuk menurunkan konsentrasi logam yang tidak kita inginkan tersebut pada tekanan yang tidak menyebabkan gangguan yang signifikan.

Pada tahap preparasi sampel, bahanbahan organik yang ada dalam sampel harus di destruksi terlebih dahulu. Ada dua prosedur yang umum digunakan untuk mendestruksi bahan-bahan organik dalam cuplikan yaitu dengan oksidasi basah (wet oxidation) dan pengabuan kering (dry 
ashing). Fungsi dari destruksi adalah untuk memutus ikatan antara senyawa organik dengan logam yang akan dianalisis. Dalam penelitian ini digunakan destruksi basah karena pada umumnya destruksi basah dapat dipakai untuk menentukan unsurunsur dengan konsentrasi yang rendah. Agar unsur-unsur tersebut tidak saling mengganggu dalam analisis, maka salah satu unsur harus di hilangkan, dengan adanya proses destruksi tersebut diharapkan yang tertinggal hanya logam-logamnya saja. Selain itu pada destruksi kering sering terjadi kehilangan unsur-unsur mikro tertentu karena suhu pemanasan yang tinggi. Di samping itu, dapat juga terjadi reaksi antara unsur dengan bahan wadah. Destruksi kering material yang berisi unsur yang rendah ditempatkan dalam wadah silika atau porselin. Unsur-unsur dalam jumlah yang cukup besar akan teradsorbsi pada permukaan wadah dengan membentuk suatu silika yang tidak dapat dihancurkan seluruhnya oleh asam. Penggunaan destruksi basah juga merujuk pada penelitian sebelumnya yaitu untuk sampel yang berbahan dasar daging maka digunakan pendestruksian basah dalam preparasinya sebelum dianalisa menggunakan SSA. Dalam preparasi destruksi basah untuk sampel yang berbahan dasar daging masih didapatkan zat pengoksidasi yang berbeda-beda seperti $\mathrm{HNO}_{3}$ p.a, $\mathrm{H}_{2} \mathrm{SO}_{4}$ p.a dan $\mathrm{H}_{2} \mathrm{O}_{2}$ p.a ataupun percampuran diantara ketiganya.

Pada penelitian kali ini, zat pengoksidasi yang utama adalah $\mathrm{HNO}_{3}$, hal ini dikarenakan sifat Timbal $(\mathrm{Pb})$ yang dapat larut dalam $\mathrm{HNO}_{3}$. Adapun reaksi yang terjadi adalah sebagai berikut:

$$
3 \mathrm{~Pb}+8 \mathrm{HNO}_{3} \rightarrow 3 \mathrm{~Pb}^{2+}+6 \mathrm{NO}_{3}{ }^{-}+2 \mathrm{NO} \uparrow+4 \mathrm{H}_{2} \mathrm{O}
$$

Adanya tambahan asam lain seperti $\mathrm{H}_{2} \mathrm{SO}_{4}$ dan $\mathrm{H}_{2} \mathrm{O}_{2}$ adalah sebagai katalis untuk mempercepat reaksi terputusnya timbal $(\mathrm{Pb})$ dari senyawa organik yang ada didalam sampel sosis sapi dan leci kaleng. Jenis katalis yang digunakan disini adalah katalis yang mempengaruhi lingkungan sehingga katalis ini tidak ikut bereaksi. Adapun reaksi yang terjadi pada larutan sampel ketika penambahan $\mathrm{H}_{2} \mathrm{SO}_{4}$ dan $\mathrm{H}_{2} \mathrm{O}_{2}$. Reaksi untuk oksidator $\mathrm{HNO}_{3}$ dan $\mathrm{H}_{2} \mathrm{SO}_{4}$ :

$$
\begin{aligned}
& 3 \mathrm{~Pb}+8 \mathrm{HNO}_{3}+\mathrm{H}_{2} \mathrm{SO}_{4} \longrightarrow \\
& 3 \mathrm{~Pb}^{2+}+6 \mathrm{NO}_{3}{ }^{-}+2 \mathrm{NO} \uparrow+4 \mathrm{H}_{2} \mathrm{O}
\end{aligned}
$$

Reaksi untuk oksidator $\mathrm{HNO}_{3}$; $\mathrm{H}_{2} \mathrm{SO}_{4}$ dan $\mathrm{H}_{2} \mathrm{O}_{2}$

$$
\begin{array}{r}
3 \mathrm{~Pb}+8 \mathrm{HNO}_{3}+\mathrm{H}_{2} \mathrm{SO}_{4} \mathrm{H}_{2} \mathrm{O}_{2} \longrightarrow \\
3 \mathrm{~Pb}^{2+}+6 \mathrm{NO}_{3}{ }^{-}+2 \mathrm{NO} \uparrow+4 \mathrm{H}_{2} \mathrm{O}
\end{array}
$$

Pada proses berikutnya dilakukan pemanasan untuk menyempurnakan destruksi . Pemanasan memberikan energi yang memungkinkan untuk memutus ikatan kimia sehingga logam $\mathrm{Pb}$ terbebas dari sampel sosis dan leci yang banyak disusun oleh senyawaan golongan polimer. Hasil destruksi selanjutnya dianalisa menggunakan SSA dengan metode kurva baku untuk kesemua oksidator tersebut sehingga kita bisa membandingkan hasil pembacaan suatu kurva terhadap ketiga oksidator tersebut ditinjau dari kestabilan data. Selanjutnya diencerkan dengan menggunakan $\mathrm{HNO}_{3}$ 0,5 M. Pengenceran menggunakan $\mathrm{HNO}_{3}$ 0,5 $\mathrm{M}$ karena kondisi yang ideal untuk suatu analisis mengunakan metode nyala SSA adalah larutan sampel yang dianalisis harus memenuhi ketentuan bahwa larutan sampel harus berada dalam matrik yang identik dengan larutan standar (Rohman, 2007).

Destruksi basah dilakukan dengan cara menguraikan bahan organik dalam larutan oleh asam pengoksidasi pekat dan panas seperti $\mathrm{H}_{2} \mathrm{SO}_{4}, \mathrm{HNO}_{3}$, dan $\mathrm{H}_{2} \mathrm{O}_{2}$ dengan pemanasan sampai volume larutan berkurang sekitar setengahnya. Mineral anorganik akan tertinggal dan larut dalam larutan asam kuat. Mineral berada dalam bentuk kation logam dan ikatan kimia dengan senyawa organik telah terurai. Larutan selanjutnya disaring dan siap dianalisis dengan SSA. 
Penentuan oksidator terbaik dilihat dari kestabilan data. Dilakukannya pengukuran kestabilan karena pada umumnya senyawa organik yang terdapat dalam sosis sapi adalah protein dan lemak sedangkan dalam sampel leci adalah karbohidrat. Untuk memecah ikatan kovalen antara karbohidrat, protein dan lemak dengan logam timbal $(\mathrm{Pb})$ harus dilakukan pendestruksian yang tepat dengan zat oksidasi yang mampu menjernihkan larutan dan mampu mempertahankan kestabilan logam timbal $(\mathrm{Pb})$ karena tidak dipungkiri adanya senyawa yang tidak larut dalam asam nitrat pekat saja. Walaupun sifat polimer seperti karbohidrat dan protein itu sendiri dapat terdenaturasi oleh asam ataupun pemanasan, namun tidak menutup kemungkinan senyawa organik lain untuk mengikat kembali logam timbal $(\mathrm{Pb})$ tersebut mengingat struktur yang sangat komplek pada sampel.

Metode pengabuan basah untuk penentuan unsur-unsur mineral di dalam bahan makanan dilakukan dengan variasi zat pengoksidasi :

1. Pengabuan menggunakan $\mathrm{HNO}_{3}$ (p),

2. Pengabuan menggunakan $\mathrm{HNO}_{3(\mathrm{p}) \text {, }}$ $\mathrm{H}_{2} \mathrm{SO}_{4}(\mathrm{p})$

3. Pengabuan menggunakan $\mathrm{HNO}_{3(\mathrm{p})}$, $\mathrm{H}_{2} \mathrm{SO}_{4}$ (p) dan $\mathrm{H}_{2} \mathrm{O}_{2}$ (p)

Berikut data destruksi sampel sosis dan leci dengan berbagai zat pendekstruksi :

Tabel 1. Destruksi sosis dan leci pada berbagai zat pendektruksi

\begin{tabular}{|l|l|l|l|l|}
\hline No & Sampel & \multicolumn{3}{|l|}{ Zat Pendekstruksi } \\
\cline { 3 - 5 } & & $\mathrm{HNO}_{3}$ & $\begin{array}{l}\mathrm{HNO}_{3} / \mathrm{H} \\
{ }_{2} \mathrm{SO}_{4} /\end{array}$ & $\begin{array}{l}\mathrm{HNO}_{3} / \\
\mathrm{H}_{2} \mathrm{SO}_{4} / \\
\mathrm{H}_{2} \mathrm{O}_{2}\end{array}$ \\
\hline 1 & $\begin{array}{l}\text { Sosis } \\
\text { Kaleng }\end{array}$ & $\begin{array}{l}\text { Ada } \\
\text { gumpalan }\end{array}$ & $\begin{array}{l}\text { Larutan } \\
\text { keruh }\end{array}$ & $\begin{array}{l}\text { Laruta } \\
\text { n jernih }\end{array}$ \\
\hline 2 & $\begin{array}{l}\text { Cairan } \\
\text { Sosis }\end{array}$ & $\begin{array}{l}\text { Larutan } \\
\text { jernih }\end{array}$ & - & - \\
\hline 3 & $\begin{array}{l}\text { Leci } \\
\text { Kaleng }\end{array}$ & $\begin{array}{l}\text { Larutan } \\
\text { keruh }\end{array}$ & $\begin{array}{l}\text { Larutan } \\
\text { jernih }\end{array}$ & - \\
\hline 4 & $\begin{array}{l}\text { Cairan } \\
\text { Leci }\end{array}$ & $\begin{array}{l}\text { Larutan } \\
\text { jernih }\end{array}$ & - & - \\
\hline
\end{tabular}

Dari Tabel 1 diketahui bahwa Sosis membutuhkan zat pendektruksi yang lebih kuat yaitu campuran dari $\mathrm{HNO}_{3} / \mathrm{H}_{2} \mathrm{SO}_{4} /$ $\mathrm{H}_{2} \mathrm{O}_{2}$ (6:2:1) untuk mencapai destruksi yang sempurna yang ditandai dengan hancurnya seluruh matriks sampel membentuk larutan yang jernih. Sosis merupakan sampel yang kaya akan protein suatu polimer asam amino dengan berat molekul yang sangat besar sehingga perlu zat pendekstruksi yang kuat. Zat pendektruksi campuran $\mathrm{HNO}_{3} / \mathrm{H}_{2} \mathrm{SO}_{4} /$ atau $\mathrm{HNO}_{3}$ saja tidak cukup kuat untuk merusak matriks sampel sehingga masih timbul warna keruh yang kemungkinan adalah protein yang belus larut bahkan gumpalan.

Sampel Leci cukup didesktruksi dengan campuran $\mathrm{HNO}_{3} / \mathrm{H}_{2} \mathrm{SO}_{4}$ (3:1) dan sudah diperoleh larutan yang jernih. Leci merupakan sampel yang kaya karbohidrat baik monosakarida (fruktosa), disakarida (sukrosa) maupun polisakarida (serat) sedangkan proteinnya hanya sedikit. Polimer sakarida cukup didestruksi dengan campuran $\mathrm{HNO}_{3} / \mathrm{H}_{2} \mathrm{SO}_{4}$ tidak memerlukan $\mathrm{H}_{2} \mathrm{O}_{2}$, namun penggunaan $\mathrm{HNO}_{3}$ masih kurang kuat sebagai zat pendektruksi. Cairan dalam makanan kaleng baik sosis maupun leci cukup didekstruksi dengan $\mathrm{HNO}_{3}$ karena pada matriks cairan tidak banyak terdapat polimer golongan protein maupun karbohidrat sehingga dapat larut sempurna dan tampak jernih.

Penambahan $\mathrm{H}_{2} \mathrm{O}_{2} \quad$ mampu mempertahankan kestabilan logam timbal $(\mathrm{Pb})$ dalam sampel sosis sapi. Hal ini dikarenakan sosis sapi kaya akan protein dan lemak sehingga ketika penambahan $\mathrm{H}_{2} \mathrm{O}_{2}$ ikatan antara timbal $(\mathrm{Pb})$ dengan senyawaan organik dalam sosis sapi terputus sehingga ketika hari ke-10 kadar timbal $(\mathrm{Pb})$ tidak terus menurun tetapi meningkat karena logam timbal $(\mathrm{Pb})$ sudah tidak diikat kembali oleh senyawaan organik yang ada namun air dalam sampel sudah menguap sehingga mengakibatkan kadar logam timbal $(\mathrm{Pb})$ meningkat.

Dari campuran antara asam-asam yang digunakan dalam pendestruksian sampel maka didapatkan bahwa campuran 
antara $\mathrm{HNO}_{3}, \mathrm{H}_{2} \mathrm{SO}_{4}$ dan $\mathrm{H}_{2} \mathrm{O}_{2}$ atau biasanya disebut dengan larutan piranha lebih kuat dalam mendestruksi logam daripada campuran dari dua larutan asam yakni $\mathrm{HNO}_{3}$ dan $\mathrm{H}_{2} \mathrm{SO}_{4}$ atau biasa disebut dengan akuaregia. Hal ini dikarenakan kekuatan asam (khususnya kalau mengikuti definisi asam bronsted) ditentukan berdasarkan tingkat ionisasi molekul asam tersebut untuk melepaskan proton. Secara kuantitatif hal ini dinyatakan dalam ukuran Ka atau pKa (Mulyono, 2005).

\section{Preparasi Sampel dengan destruksi Kering}

Sampel sosis maupun leci juga dipreparasi dengan cara destruksi kering. Sampel diabukan dalam suhu tanur $500 \mathrm{C}$ sampai menjadi abu dengan waktu 2 jam. Sampel sosis yang berwarna kecoklatan dan leci yang berwarna puth menjadi serbuk berwarna putih keabu abuan. Warna putih keabu abuan merupakan zat anorganik yang tidak menguap termasuk mineral. Tujuan dari pengabuan adalah agar mineral yang terdapat didalam sampel sosis dan leci dapat terlepas dari matriks senyawa besar seperti protein, lemak dan karbohidrat.

Metode destruksi kering menggunakan temperatur $>500^{\circ} \mathrm{C}$ untuk mendestruksi dan menguapkan senyawa organik dari $\mathrm{C}, \mathrm{H}, \mathrm{O}$ dan $\mathrm{N}$ menjadi gas gas seperti $\mathrm{CO}_{2}, \mathrm{CO}, \mathrm{NO}, \mathrm{NO}_{2}, \mathrm{H}_{2} \mathrm{O}$, dan sebagainya . Keuntungan metode ini adalah sederhana dan terhindar dari pengotor seperti dalam metode destruksi basah, namun dapat terjadi kehilangan unsur-unsur mikro tertentu. Di samping itu, dapat juga terjadi reaksi antara unsur dengan bahan wadah. Destruksi kering material yang berisi unsur yang rendah ditempatkan dalam wadah silika atau porselin.

\section{Analisis Pb dalam sampel menggunakan destruksi kering}

Sampel sosis maupun leci diabukan dalam suhu tanur $500 \mathrm{C}$ sampai menjadi abu dengan waktu 2 jam. Tujuan dari pengabuan adalah agar mineral yang terdapat didalam sampel sosis dan leci dapat terlepas dari matriks senyawa besar seperti protein, lemak dan karbohidrat. Metode destruksi kering menggunakan temperatur $>500^{\circ} \mathrm{C}$ untuk mendestruksi dan menguapkan senyawa organik dari $\mathrm{C}, \mathrm{H}, \mathrm{O}$ dan $\mathrm{N}$ menjadi gas gas seperti $\mathrm{CO}_{2}, \mathrm{CO}$, $\mathrm{NO}, \mathrm{NO}_{2}, \mathrm{H}_{2} \mathrm{O}$, dan sebagainya. Abu yang diperoleh selanjutnya dilarutkan dengan $\mathrm{HNO}_{3}$ (p) dan dianalisis dengan AAS. Hasil analisis ditunjukkan pada tabel berikut :

Tabel 2. Kadar $\mathrm{Pb}$ dalam berbagai sampel dekstruksi kering

\begin{tabular}{|l|l|}
\hline Sampel & Kadar Pb (ppm) \\
\hline Sosis & 0,21 \\
\hline Leci & 0,12 \\
\hline
\end{tabular}

Dari tabel di atas diketahui bahwa kadar $\mathrm{Pb}$ dalam leci maupun sosis cukup kecil. Bahkan sebelumnya kadar $\mathrm{Pb}$ terbaca 0 ppm pada beberapa kali ulangan. Hal ini disebabkan saat pengabuan dengan tanur ada sebagian dari $\mathrm{Pb}$ yang semula terikat dengan matriks polimer seperti karbohidrat dan protein belum dapat terdekstruksi keseluruhan sehingga sebagian senyawa organik masih mengikat $\mathrm{Pb}$. Kemungkinan juga beberapa senyawa teradsorbsi pada permukaan wadah silikat termasuk $\mathrm{Pb}$ sehingga saat analisis $\mathrm{Pb}$ yang terdeteksi cukup kecil. Pemilihan pelarut saat proses pelarutan abu menggunakan larutan $\mathrm{HNO}_{3}$ 0,5 M diduga juga tidak mampu larut sempurna sehingga kadar $\mathrm{Pb}$ terbaca sangat rendah.

\section{Analisis Pb dalam sampel makanan kaleng}

Analisis $\quad \mathbf{P b}$ dalam sampel yang dipreparasi dengan destruksi basah

Sampel yang digunakan dalam penelitian ini adalah sosis dan leci dan dipilih sampel yang tidak kedaluarsa. Sampel dibedakan menjadi 2 yaitu bagian cair dan padatan. Zat pendekstruksi yang digunakan berturut turut adalah $\mathrm{HNO}_{3}(\mathrm{p})$, campuran $\mathrm{HNO}_{3}$ (p), $\mathrm{H}_{2} \mathrm{SO}_{4}$ (p) 3:1, dan campuran $\mathrm{HNO}_{3}$ (p), $\mathrm{H}_{2} \mathrm{SO}_{4}$ (p) dan $\mathrm{H}_{2} \mathrm{O}_{2}$ (p) 6:2:1. 
Tabel 3. Kadar $\mathrm{Pb}$ dalam berbagai sampel dengan menggunakan $\mathrm{HNO}_{3}$ sebagai agen pendekstruksi

\begin{tabular}{|l|l|l|l|l|l|}
\hline Sampel & \multirow{2}{*}{$\begin{array}{l}\text { penyimpan } \\
\text { an }\end{array}$} & \multicolumn{4}{|c|}{$\begin{array}{l}\text { Kadar Pb (ppm) dalam 4 } \\
\text { ulangan }\end{array}$} \\
\cline { 3 - 6 } & & 1 & 2 & 3 & 4 \\
\hline $\begin{array}{l}\text { Sosis } \\
\text { kering }\end{array}$ & 0 hari & 0,26 & 0,17 & 0,12 & 0,08 \\
\hline $\begin{array}{l}\text { Leci } \\
\text { kering }\end{array}$ & 0 hari & 0,27 & 0,08 & 0,19 & 0,15 \\
\hline $\begin{array}{l}\text { Sosis } \\
\text { kering }\end{array}$ & 7 hari & 0 & 0 & 0 & 0 \\
\hline $\begin{array}{l}\text { Leci } \\
\text { kering }\end{array}$ & 7 hari & 0 & 0 & 0 & 0 \\
\hline
\end{tabular}

Dari tabel di atas diketahui bahwa zat pendekstruksi $\mathrm{HNO}_{3}$ pekat ternyata memberikan hasil yang tidak konsisten dan tidak stabil baik untuk sampel leci ataupun sosis. Hal ini diketahui dari hasil analisis 4 ulangan yang tidak stabil dan tidak dibaca trendnya. Ketidakstabilan ini disebabkan karena sampel tidak terdekstruksi sempurna sehingga aada sebagian $\mathrm{Pb}$ yang masih terikat dengan matriks sampel yang kaya akan polimer karbohidrat dan protein. Ketidak stabilan kadar $\mathrm{Pb}$ juga diketahui darai hasil analisis sampel yang disimpan selama 7 hari. Hasil analisis kadar $\mathrm{Pb}$ dalam sampel yang disimpan selama 7 hari terbaca 0 ppm dikarenakan $\mathrm{Pb}$ mengendap kembali bersama polimer terlarut didalamnya sehingga logam $\mathrm{Pb}$ yang berada dalam filtrat tidak diketemukan. Hal ini disebabkan pendekstruksi $\mathrm{HNO}_{3}$ kurang kuat untuk merusak matriks sampel yang membebaskan $\mathrm{Pb}$ agar dapat terlarut sempurna dan ketika disimpan selama 7 hari maka polimer sampel dapat mengendapkan $\mathrm{Pb}$ kembali.

Ketika preparasi diketahui bahwa sosis membutuhkan zat pendektruksi yang lebih kuat yaitu campuran dari $\mathrm{HNO}_{3} / \mathrm{H}_{2} \mathrm{SO}_{4} / \mathrm{H}_{2} \mathrm{O}_{2}$ (6:2:1) untuk mencapai destruksi yang sempurna yang ditandai dengan hancurnya seluruh matriks sampel membentuk larutan yang jernih. Hasil destruksi sampel dianalisis kadar $\mathrm{Pb}$ didalamnya seperti Ttabel 5.
Tabel 4. Kadar $\mathrm{Pb}$ dalam sampel sosis dengan menggunakan $\mathrm{HNO}_{3}(\mathrm{p}), \mathrm{H}_{2} \mathrm{SO}_{4}(\mathrm{p})$ dan $\mathrm{H}_{2} \mathrm{O}_{2}$ (p) 6:2:1. sebagai agen pendekstruksi

\begin{tabular}{|l|l|l|l|l|l|}
\hline & \multicolumn{4}{|l|}{ Kadar Pb (ppm) } \\
\hline Ulangan & 1 & 2 & 3 & 4 & 5 \\
\cline { 2 - 6 } & 0,59 & 0,68 & 0,65 & 0,60 & 0,68 \\
\hline
\end{tabular}

Dari Tabel 4 di atas didapatkan data bahwa kadar $\mathrm{Pb}$ dalam sosis yang didestruksi dengan $\mathrm{HNO}_{3}$ (p), $\mathrm{H}_{2} \mathrm{SO}_{4}$ (p) dan $\mathrm{H}_{2} \mathrm{O}_{2}$ (p) 6:2:1 dalam 5 kali ulangan sudah cukup teliti. Hal ini diketahui dari data tertinggi $(0,68 \mathrm{ppm})$ dan terendah $(0,59 \mathrm{ppm})$ dan rata rata $0,64 \mathrm{ppm}$. Sosis merupakan sampel yang kaya akan protein suatu polimer asam amino dengan berat molekul yang sangat besar sehingga perlu zat pendekstruksi yang kuat. Zat pendekstruksi campuran $\mathrm{HNO}_{3}(\mathrm{p}), \mathrm{H}_{2} \mathrm{SO}_{4}$ (p) dan $\mathrm{H}_{2} \mathrm{O}_{2}$ (p) 6:2:1 sudah cukup kuat untuk merusak matriks sehingga $\mathrm{Pb}$ dapat terlarut dalam filtrat dengan sempurna. $\mathrm{Pb}$ yang terlarut relatif stabil dalam pelarut zat asam kuat dan $\mathrm{Pb}$ tidak dapat mengendap kembali karena diperkirakan sebagian besar polimer telah terhidrolisis.

Sampel Leci cukup didesktruksi dengan campuran $\mathrm{HNO}_{3} / \mathrm{H}_{2} \mathrm{SO}_{4}$ (3:1) dan sudah diperoleh larutan yang jernih. Leci merupakan sampel yang kaya karbohidrat baik monosakarida (fruktosa), disakarida (sukrosa) maupun polisakarida (serat) sedangkan proteinnya hanya sedikit. Polimer sakarida cukup didestruksi dengan campuran $\mathrm{HNO}_{3} / \mathrm{H}_{2} \mathrm{SO}_{4}$ tidak memerlukan $\mathrm{H}_{2} \mathrm{O}_{2}$. Hasil analisis kadar $\mathrm{Pb}$ dalam sampel leci ditunjukkan pada tabel berikut :

Tabel 5. Kadar $\mathrm{Pb}$ dalam sampel leci dengan menggunakan $\mathrm{HNO}_{3}$ (p), $\mathrm{H}_{2} \mathrm{SO}_{4}$ (p) 3:1. sebagai agen pendekstruksi

\begin{tabular}{|l|l|l|l|l|l|}
\hline & \multicolumn{4}{|l|}{ Kadar $\mathrm{Pb}(\mathrm{ppm})$} \\
\hline Ulangan & 1 & 2 & 3 & 4 & 5 \\
\cline { 2 - 6 } & 0,68 & 0,72 & 0,69 & 0,65 & 0,70 \\
\hline
\end{tabular}

Dari Tabel 5 di atas didapatkan data bahwa kadar $\mathrm{Pb}$ dalam leci yang didestruksi dengan $\mathrm{HNO}_{3}$ (p), $\mathrm{H}_{2} \mathrm{SO}_{4}$ (p) 3:1 dalam 5 kali ulangan sudah cukup teliti. Hal ini diketahui dari data tertinggi $(0,72 \mathrm{ppm})$ dan 
terendah $(0,65 \mathrm{ppm})$ dan rata rata 0,688 ppm. Leci merupakan sampel yang kaya akan karbohidrat khususnya gula dan memerlukan zat pendekstruksi campuran $\mathrm{HNO}_{3}$ (p), $\mathrm{H}_{2} \mathrm{SO}_{4}$ 3:1 sudah cukup kuat untuk merusak matriks sehingga $\mathrm{Pb}$ dapat terlarut dalam filtrat dengan sempurna. $\mathrm{Pb}$ yang terlarut relatif stabil dalam pelarut zat asam kuat dan $\mathrm{Pb}$ tidak dapat mengendap kembali karena diperkirakan sebagian besar polimer telah terhidrolisis.

Cairan dalam makanan kaleng baik sosis maupun leci cukup didekstruksi dengan $\mathrm{HNO}_{3}$ karena pada matriks cairan tidak banyak terdapat polimer golongan protein maupun karbohidrat sehingga dapat larut sempurna dan tampak jernih. Cairan dari sosis dan leci kalengan didestruksi dengan $\mathrm{HNO}_{3}$ dan menunjukkan hasil yang cukup stabil jika ditinjau dari 3 kali ulangan. Hal ini disebabkan matriks cairan pada sosis dan leci kaleng termasuk zat cair yang cukup encer sehingga mudah membuat $\mathrm{Pb}$ cukup larut. Hasil analisis cairan pada sosis dan leci kaleng ditunjukkan pada tabel berikut :

Tabel 7. Kadar $\mathrm{Pb}$ dalam berbagai sampel dengan menggunakan $\mathrm{HNO}_{3}$ sebagai agen pendekstruksi

\begin{tabular}{|l|l|l|l|}
\hline \multirow{2}{*}{ Sampel } & \multicolumn{3}{|l|}{ Kadar Pb (ppm) dalam 3 } \\
ulangan
\end{tabular}

Cairan dari leci dan sosis kaleng juga dicoba dengan zat pendekstruksi $\mathrm{HNO}_{3}$ (p), $\mathrm{H}_{2} \mathrm{SO}_{4}$ (p) dan $\mathrm{H}_{2} \mathrm{O}_{2}$ (p) 6:2:1 meskipun dengan $\mathrm{HNO}_{3}$ (p) saja sudah cukup jernih dan memberikan hasil yang cukup teliti dari 3 kali ulangan. Kadar $\mathrm{Pb}$ dalam berbagai sampel dengan menggunakan $\mathrm{HNO}_{3}$ dan asam sulfat dan peroksida sebagai agen pendekstruksi ditunjukkan pada Tabel 8.

Dari hasil analisis $\mathrm{Pb}$ seperti Tabel 8 ternyata zat pendekstruksi $\mathrm{HNO}_{3}$ (p), $\mathrm{H}_{2} \mathrm{SO}_{4}$ (p) dan $\mathrm{H}_{2} \mathrm{O}_{2}$ (p) 6:2:1 memberikan hasil rata rata konsentrasi $\mathrm{Pb}$ hampir 2 kali lipat daripada $\mathrm{HNO}_{3}$ (p) saja. Hal ini disebabkan karena zat pendektruksi $\mathrm{HNO}_{3}$ (p), $\mathrm{H}_{2} \mathrm{SO}_{4}$ (p) dan $\mathrm{H}_{2} \mathrm{O}_{2}$ (p) 6:2:1 jauh lebih kuat daripada $\mathrm{HNO}_{3}$ (p) saja untuk melarutkan $\mathrm{Pb}$ sebagai kation logam bebas. Meskipun secara fisik kedua sampel dengan zat pendektruksi yang berbeda terlihat jernih namun hasil analisis nya berbeda cukup jauh. Hasil analisis $\mathrm{Pb}$ dalam 2 jenis sampel cair tersebut menyimpulkan bahwa zat pendestruksi $\mathrm{HNO}_{3}$ (p), $\mathrm{H}_{2} \mathrm{SO}_{4}$ (p) dan $\mathrm{H}_{2} \mathrm{O}_{2} \quad$ (p) 6:2:1 lebih efektif untuk melarutkan $\mathrm{Pb}$ dalam sampel cair dibandingkan $\mathrm{HNO}_{3}$ (p) dilihat dari kestabilan sampel dan hasil yang diperoleh.

Tabel 4.8. Kadar $\mathrm{Pb}$ dalam berbagai sampel dengan menggunakan $\mathrm{HNO}_{3}(\mathrm{p}), \mathrm{H}_{2} \mathrm{SO}_{4}(\mathrm{p})$ dan $\mathrm{H}_{2} \mathrm{O}_{2}$ (p) 6:2:1 sebagai agen pendekstruksi

\begin{tabular}{|c|c|c|c|}
\hline \multirow[t]{2}{*}{ Sampel } & \multicolumn{3}{|c|}{$\begin{array}{llll}\text { Kadar } & \mathrm{Pb} & (\mathrm{ppm}) & \text { dalam } \\
\text { ulangan } & & & \\
\end{array}$} \\
\hline & 1 & 2 & 3 \\
\hline Sosis cair & 0,46 & 0,48 & 0,42 \\
\hline Leci cair & 0,45 & 0,47 & 0,45 \\
\hline
\end{tabular}

Kadar logam Timbal $(\mathrm{Pb})$ dalam sampel sosis dan leci kaleng baik pada sampel padat dan cairannya masih memenuhi syarat yaitu dibawah $1 \mathrm{ppm}$ dan melebihi ambang batas S.K Dirjen BPOM No. 03725/B/SK/VII/89. Hal ini dapat dimungkinkan karena kaleng sebagai wadah makanan olahan telah mengandung logam $\mathrm{Pb}$, dan senyawa-senyawa dalam sampel tercemar logam berat $\mathrm{Pb}$. Interaksi bahan makanan olahan dengan wadahnya memang tidak dapat dihindarkan namun semakin lama interaksi maka kemungkinan kadar $\mathrm{Pb}$ akan semakin besar. Konsumsi makanan kaleng sebaiknya memperhatikan masa kedaluarsa agar cemaran $\mathrm{Pb}$ tidak berlebihan terakumulasi pada konsumen.

\section{Kajian Hasil Penelitian tentang Makanan yang Halal dan Baik dalam Perspektif Islam}

Ajaran Islam mencakup seluruh aspek kehidupan, tak terkecuali masalah makanan. Oleh karena itu bagi kaum 
muslimin, makanan di samping berkaitan dengan pemenuhan kebutuhan fisik, juga berkaitan dengan ruhani, iman dan ibadah juga dengan identitas diri, bahkan dengan perilaku (Suprayatmi, 2011).

Allah SWT berfirman dalam Al-quran surat Al-Baqarah ayat 168 sebagai berikut:

Artinya : Hai sekalian manusia, makanlah yang halal lagi baik dari apa yang terdapat di bumi, dan janganlah kamu mengikuti langkah-langkah syaitan; karena sesungguhnya syaitan itu adalah musuh yang nyata bagimu (Q.S Al Baqarah:168).

Ayat di atas menjelaskan, makanan yang halal dan baik dapat menentukan perkembangan rohani dan pertumbuhan jasmani kearah positip dan diridoi Allah didunia dan diakhirat, kalau tidak manusia akan berwatak syetan di dunia ini dan diancam dengan siksaan neraka pada hari kiamat kelak (Mustafa, 1992).

Selain surat Al-Baqarah ayat 168 terdapat pula ayat Al-Maidah ayat 88 Artinya :"Dan makanlah makan yang halal lagi baik dari apa yang Allah telah telah berikan rezekinya kepadmu bertaqwalah pada Allah yang kamu beriman padaNya."(QS. Al Maidah : 88).

Ayat di atas menjelaskan bahwa Allah memerintahkan kepada kita untuk memilih makanan yang halal dan baik. Halal berarti sesuatu yang dibolehkan oleh syariat, sedangkan baik berarti perkara yang dinikmati oleh diri dan dicenderungi hati, yang dapat juga diartikan makanan yang bergizi, menyehatkan dan tidak membahayakan bagi tubuh dan akal (Mustafa, 1992).

Oleh sebab itu, maka di dalam memilih makanan yang halal tetapi baik dan yang baik tetapi halal ini, selain daripada yang ditentukan oleh Allah, diserahkan juga dalam ijtihad kita sendiri memilih mana yang halal dan baik. Itu sebabnya ujung ayat berbunyi: "Dan bertakwalah kepada Allah yang kamu beriman keada-Nya”. Ketentuan Allah tentang halal dan baik, lalu diserahkan kepada pertimbangan batin, yaitu takwa dan iman, bertambah penting memilih makanan dan minuman yang layak di dunia ini. Itu sebabnya, apabila hendak memakan suatu makanan, disuruh dengan tekanan keras agar membaca Bismillah dan setelah makan disuruh pula dengan tekanan keras memuji Allah: Alhamdulillah.

Organ tubuh yang dipergunakan untuk melakukan metabolisme dan penyerapan zat makanan akan lebih mudah terserang penyakit apabila konsumsi makanan melebihi batas yang dibutuhkan oleh tubuh.

Pada tubuh manusia makanan mengalami proses pengolahan yang meliputi pencernaan, penyerapan dan metabolisme. Zat makanan dibutuhkan sebagai sumber energi, sedangkan zat makanan yang tidak tercerna oleh enzim pendegradasi pangan akan menjadi serat pangan yang menyehatkan saluran pencernaan. Makanan merupakan sumber energi yang akan mengalir pada darah manusia, jadi jika makanan yang dimakan adalah makanan yang halal dan memiliki nilai gizi tinggi maka diharapkan akan mendorong seseorang untuk lebih sehat dan lebih mudah menjalankan aktivitas .

Pada penelitian ini, didapatkan hasil bahwa kadar logam timbal $(\mathrm{Pb})$ masih berada dibawah ambang batas yang telah ditentukan oleh BPOM dan SNI. Hal ini juga memenuhi kriteria makanan yang baik yaitu (Ahira, 2010):

- Tidak mengandung zat kimia berlebihan

- Tidak mengandung zat pewarna kimia

- Tidak mengandung zat pengawet makanan

Allah SWT telah memberikan makanan halal sebagai rezeki untuk kita dan kita perlu mensyukuri dan bertakwa kepadaNya. Bertakwa dalam hal makanan menuntut agar setiap makanan yang dicerna tidak mengakibatkan penyakit dan aman bagi yang mengkonsumsi . Dengan memenuhi makan yang memenuhi unsur gizi yang lebih baik (thayyib) diharapkan tubuh berada dalam keadaan yang optimal sehingga daya tahan tubuh akan bekerja 
secara maksimal dalam menolak segala macam penyakit. Manusia hendaknya berfikir tentang berbagai karunia Allah SWT yang telah diberikan kepada manusia. Allah SWT telah mengatur kehidupan ini dengan sempurna dan dengan penuh keseimbangan seperti yang telah tersurat dalam Al-Qur'an dan telah terbukti dalam kehidupan. Oleh karena itu, marilah kita lakukan segala perintahnya dan menjauhi segala larangannya.

\section{KESIMPULAN DAN SARAN}

\section{Kesimpulan}

Dari penelitian didapatkan beberapa kesimpulan dan saran yaitu :

Zat pengoksidasi terbaik untuk mendesktrusi sampel sosis untuk analisis $\mathrm{Pb}$ adalah adalah $\mathrm{HNO}_{3}$ (p), $\mathrm{H}_{2} \mathrm{SO}_{4}$ (p) dan $\mathrm{H}_{2} \mathrm{O}_{2}$ (p) 6:2:1, untuk sampel leci adalah $\mathrm{HNO}_{3} \quad$ (p), $\mathrm{H}_{2} \mathrm{SO}_{4} \quad$ (p) 3:1, sedangkan sampel cair baik pada sosis maupun leci adalah $\mathrm{HNO}_{3}$ (p), $\mathrm{H}_{2} \mathrm{SO}_{4}$ (p) dan $\mathrm{H}_{2} \mathrm{O}_{2}$ (p) 6:2:1.

Analisis sosis dan leci menggunakan desktruksi basah memberikan hasil hampir 3 kali dibandingkan dengan dekstruksi kering. Desktruksi basah lebih efektif diterapkan untuk sosis dan leci daripada destruksi kering

\section{Saran}

Perlu dilakukan Penelitian tentang kandungan logam berat lain dalam sosis maupun leci kaleng.

Perlu dicoba metode adisi standar untuk analis is $\mathrm{Pb}$ dalamn sosis dan leci kaleng

\section{DAFTAR PUSTAKA}

Aziz, V. 2007. Analisis kandungan logam Timah, Seng dan Timbal pada sampel Susu Kental Manis kemasan kaleng menggunakan Spektrofotometri Serapan Atom. Skripsi Jurusan Kimia UII Yogyakarta
Cahyadi, W. 2004. Bahaya Pencemaran Timbal pada Makanan dan Minuman.

Day and Underwood. 2002. Analisis Kimia Kuantitatif. Jakarta: Erlangga

Destrosier, M.N. 1988. Teknologi Pengawetan Pangan. Jakarta: UI Press

James, C.J. 1999. Analytical Chemistry Of Foods. An Aspen Publication, Gaihthersburg : Maryland

Khopkar, S.M. 1990. Konsep Dasar Kimia Analitik. Jakarta: UI Press

Khozanah, H., 2004, Penentuan Kandungan $\mathrm{Pb}$ dan $\mathrm{Cu}$ pada sayuran sawi dengan AAS. Skripsi Jurusan Kimia UII Yogyakarta

Maria, S. 2010. Penentuan kadar logam besi $(\mathrm{Fe})$ dalam tepung gandum dengan cara destruksi basah dan destruksi kering dengan spektroskopi serapan atom (SSA). Skripsi Jurusan Kimia Fakultas MIPA Universitas Sumatera Utara

Miller, J.C. 1991. Statistika untuk Kimia Analitik. Bandung : ITB Press

Mulyono. 2005. Kamus Kimia. Jakarta: Bumi Aksara

Mustofa, A. 1992. Terjemah Tafsir AlMaraghi. Semarang: CV. Toha Putra

Rohman, A. 2007. Kimia Farmasi Analisis. Yogyakarta: Pustaka Pelajar

Surtipanti. 2005. Penentuan logam berat dalam daging, usus, Hati, ayam dan telur dengan spektroskopi serapan atom. Journal Center for the Application of Isotopes Radiation, BATAN 